\title{
Strategic and Tactical Planning in the Management of Financial and Economic Security of Enterprises: Financial Component
}

\author{
Tetiana Gogol \\ Department of Accounting, Taxation \\ and Auditing \\ Chernihiv National University of \\ Technology \\ Chernihiv, Ukraine \\ tatyanagogoll@gmail.com \\ https://orcid.org/0000-0002-0885-6271
}

\author{
Valentin Nekhai \\ Department of Accounting, Taxation \\ and Auditing \\ Chernihiv National University of \\ Technology \\ Chernihiv, Ukraine \\ valentin_nehai@meta.ua \\ https://orcid.org/0000-0002-9548-0961
}

\author{
Vadym Kolotok \\ Department of Accounting, Taxation \\ and Auditing \\ Chernihiv National University of \\ Technology \\ Chernihiv, Ukraine \\ kolotokvo@ukr.net \\ https://orcid.org/0000-0002-1577-4944
}

\begin{abstract}
Transformation of the national economy, as a response to the latest developments in the global economy, which are characterized by various controversial and unexpected processes, requires revaluation and consideration of adequate tools of financial and economic security policy for enterprises, including small businesses. One of essential components of economic security is ensuring of the enterprise funding. It is possible to solve this problem by introducing strategic and tactical planning in the financial management for small business enterprises. The purpose of the following article is to review, estimate and adapt the existing methods and approaches of tactical and strategic planning of corporate finance as an integral part of financial and economic security of the enterprise, thus regarding small business entities. Presentation of own vision on the methodological basis in developing a financial component of small business strategy. It has been established that financial planning for small enterprises should be in line with the basic principles: scientific character, goal orientation, consistency, steadiness and flexibility, coordination, correspondence of funding sources to their goals, provision of liquidity and financial sustainability. It has been revealed that formation of financial plans for small businesses has certain problems such as: limited accounting staff, requiring the relevant professional competences of the latter; lack of managerial accounting; insufficient funding for creation of appropriate accounting and analytical system. The main directions for organisation of financial planning at small enterprises has been offered, taking into account the limited resources.
\end{abstract}

Keywords - financial and economic security, small business, strategy, tactics, planning, management.

\section{INTRODUCTION}

Small business has an extensive role in the economy of Ukraine. The huge merit of small business enterprises, despite all their problems, is creation of jobs under conditions of the crisis state of our country's economy. Farming enterprises are of particular emphasis within the present circumstances. Complete development of small businesses affects the growth in prosperity of local communities and society as a whole. Without exaggeration, small business is one of those which provides economic stability and security of our state. It undoubtedly contributes to the transformation of our economy in the context of European integration, making it more competitive and more efficient.
Numerous research works has been devoted to theoretical and methodological aspects of strategic planning. Considerable contribution to the solution of this problem has been made by such Ukrainian scientists as Kireitsev H.H. [6], Chumachenko N.H. [7]. However, the issue of substantiating strategic planning at the enterprises in modern conditions, characterized by a conflict, risk and uncertainty, remains urgent even today

The issue of financial planning has been considered in the works Yu.O. Lytvyn, V.I. Matviychuk [2], Scherban O.D. [3] and others.

Formation of financial strategy of the enterprise has been investigated in the works of native scientists: Lazarenko D., Sirenko S. [5]. At the same time it should be noted, that the essence and features of strategic financial planning of agricultural enterprises, especially small businesses, receive much less attention both in national and foreign literature.

Problems of economic security of agricultural enterprises have been covered in the works by $\mathrm{V}$. Zhyvotenko [12], G. Kozachenko [13]. Still, certain elements of financial and economic security system of agricultural enterprises, such as strategic financial planning, remain unexplored.

The events of recent years have been characterized by significantly diverse, contradictory and unexpected processes in the global economy, which require reassessment and development of adequate tools for economic security policy of enterprises, including small businesses, aimed at both strengthening the current state and ensuring sustained long-term dynamics. One of important components of economic security is ensuring the corporate financing. It is possible to solve the following issue by introducing strategic and tactical planning in the financial management for small business enterprises.

\section{PRESEntation OF BASIC MAterial}

Generally, corporate finance is comprehended as a system of relations associated with the movement of funds at all stages (formation, distribution and use) of activities of the enterprise in order to ensure its functioning and conditions of extended reproduction [1]. 
Strategic and tactical management of finance for small businesses can be implemented through appropriate planning. It should take place at all stages of the movement of funds: formation, distribution and use.

In spite of considerable attention of practitioners and scholars to the issues of financial planning, there has not been any single interpretation yet. However, the majority of experts consider financial planning as a system that includes concepts, objects, subjects, goals, principles, tasks and functions. [2]

In view of applying the systematic approach, financial planning should be considered as continuous monitoring, preparation of managerial decisions on determination of the amount of financial resources, sources of their formation and targeted use, which are formalised into financial budget with the aim to achieve certain strategic goals.

The basis for making out a financial plan is the strategy of the enterprise operation, part of which is a financial strategy, developed in accordance with principles and methods of financial policy.

Financial planning, like any other process of planning, involves compliance with certain conditions that will ensure the expected result. This, first of all, requires observance of certain principles and methods that determine the algorithm and content of the planning process. The applied planning methods should be in line with internal and external conditions of management, taking into account the specificity of activities of the planning objects as well as variety of means and options for achieving their strategic goal [3].

Financial policy of the enterprise is formed upon the following basic principles: scientific validation, purposefulness, systemic approach, steadiness, adaptability, coordination, targeted use of financing sources, ensuring of financial stability [4].

Financial planning at small business enterprises is divided into strategic and tactical planning.

Most researchers believe that strategic planning is essentially directed at predicting the future state of external environment, identification of possible risks and development of an appropriate strategy for the enterprise operation.

In terms of financial aspect, strategic plans contain the main financial indicators, volume and structure of financial resources, sources of formation, investment strategies.

As noted by D. Lazarenko and S. Sirenko [5]: "Strategic financial planning requires creation of new mechanisms for financial management of the enterprise, which would allow to evaluate and optimize future financial and economic activities at the stage of planning, to identify reserves for improving the profitability of products by optimizing their nomenclature and commercialisation of effective product innovations".

Strategic financial plans are developed for several years. For small businesses, it is important to include the following information into strategic plans:

- production forecast;

- sales projection;
- forecast of incoming and outgoing movement of funds;

- forecast of possible revenues, expenses and financial results;

- estimation of investment promotion;

- projected balance sheet of assets and liabilities;

- estimation of break-even point and safety margin;

- indicators that reflect specifics of activities.

Forecasting production and sales volumes allows the manager to identify possible reserves for increasing production and sales.

Appropriate forecast of production and sales volumes makes it possible to predict cash inflows and expenditures and, accordingly, possible accrual of income and expenses in order to calculate the potential financial result.

Estimation of investment attraction allows to reveal possible revenues from investors. Such forecasting can be carried out by analysing previous investments into the enterprise.

Projection of the balance sheet of assets and liabilities provides the managerial personnel with information on the possible state of assets, liabilities and owned capital as for the forecast day.

In the process of profit planning, it is necessary to determine the threshold at which the enterprise will be unprofitable. For this purpose, such indicators as a breakeven point and a safety margin are calculated.

Calculation of the break-even point consists in determination of the point of make-out (break-even point) that is, the definition of such a minimum sales volume, at which the enterprise will not bear any losses [6].

Prerequisite for calculating the threshold of break-even activity is distribution of costs of the enterprise operation on fixed factors (the amount of expenses does not depend on production volumes) and variables (expenses which correlate to changes in production volumes).

To analyse the manner of costs, taking into account a certain factor, logical and mathematical methods are applied [7]:

- method of account analysis;

- method of in-process analysis (engineering approach);

- visualization method;

- method of minimum and maximum points (absolute growth approach);

- method of regression analysis.

In physical terms, the break-even point can be determined by the following formula (1):

$$
\mathrm{Q}=\mathrm{FC} /(\mathrm{P}-\mathrm{AVC})
$$

where: Q is a break-even point (physical volume of sales);

FC is an amount of constant expenses; 
$\mathrm{P}$ is a price per production unit;

AVC are variable costs per production unit.

In monetary terms, in the case of selling several types of products, the break-even point can be determined by the following formula (2):

$$
\begin{gathered}
\mathrm{Q}=\mathrm{FC} / \mathrm{Km} \\
\mathrm{Km}=\mathrm{GM} / \mathrm{TR} \\
\mathrm{GM}=\mathrm{TR}-\mathrm{VC}
\end{gathered}
$$

where: $\mathrm{Q}$ is a break-even point (sales volume in monetary terms);

FC is an amount of constant expenses;

$\mathrm{Km}$ is a gross margin ratio;

GM is a gross margin;

VC are total variable costs;

$\mathrm{TR}$ is sales revenue.

Determination of the break-even point indicates a sufficient volume of sales, which can provide coverage of all expenses, while a margin-of-safety indicator displays the real financial state of the enterprise. Its task is to show how close the company has come to the point at which losses can start [8].

Estimation of the safety margin is carried out in absolute values in both physical and monetary terms. In the first case, the safety margin is calculated as the difference between the actual sales volume and at the break-even point in physical terms, while in the second case it is calculated in monetary terms. The relative margin-of-safety index is further calculated by dividing the corresponding figures [9].

An integral part of financial planning is the forecast of indicators, which correspond to specifics of the enterprise. For example, agrarian enterprises should take into account those indicators, which characterize not only the technical and technological state, as well as economic and labour relations, but also natural and environmental conditions.

Formalized strategy in financial planning defines a list of tasks and indicates a set of actions aimed at its implementation. Detailed elaboration in the form of tactical goals and tasks is reflected in the short-term plans [10].

Unlike strategic planning, which defines the indicative level of the given parameters, the task of current planning is to coordinate directions of investments with the sources of their financing, together with analysing the efficiency of alternative sources of financing, as well as conducting financial evaluation of different directions of activities of the enterprise and their effectiveness.

Tactical planning is usually worked out for one year. It includes the same indicators as in strategic planning.

Development of financial plans at small enterprises, given to the limited amount of accounting staff, can be completed by the chief executive, providing the availability of relevant educational competencies. Nevertheless, it is obvious that in the process of development of the following plans consideration should be given to the opinion of management.
Despite significant practice in the sphere of financial planning, there are still particular implementation and application problems, especially at small business enterprises, regarding this instrument and aiming to ensure financial and economic security of economic entities.

As noted by T. Kirsanova and N. Diachenko [11], first of all, the following problems are associated with the unreality of financial plans: unjustified sales volumes (overstatement); miscalculations in the structure and timing of repayment of accounts receivable; excessive funding needs. Secondly, there is the problem of operational efficiency of planning. Two previous problems cause the third one, which is "non-transparency" of plans in relation to the chief personnel. Moreover, these problems are directly related to the implementation of plans: flexibility, degree of execution, disproportions between revenues and expenditures, breach of deadlines for repayment of accounts receivable. Thirdly, there is the problem of complexity of plans: the consistency between different types of expenditures, current analysis of the plan implementation, conditions and reasons that may lead to deviations of actual indicators from the planned ones.

Thus, financial planning, as a component of the enterprise management, includes the following steps: formalisation of a problem; working out alternative options for problem solving; effectiveness assessment; decision making; implementation of the plan; monitoring.

It is important for the management of small business entities to work out an appropriate procedure for development and approval of financial plans in order to identify their forms, content and responsible persons for preparation, approval, implementation and monitoring of these plans. In accordance with this order, the following issues should be agreed upon:

- identification of persons responsible for development and approval of the forms of financial plans;

- identification of persons responsible for preparation and implementation of financial plans;

- identification of persons responsible for approval of a competed plan and monitoring of its implementation;

- determination of goals for each of the plans;

- definition of indicators that should be included in the following plans;

- development and approval of forms of financial plans.

Drawing of financial plans should take place in four stages: selection and preparation of the necessary information; introduction of information into tables and plotting of diagrams; writing of explanatory statements; submission of the prepared plan, its approval and further monitoring of its implementation. Each of the following steps should be taken into account.

Selection and preparation of relevant information. All the information required should be collected and systemised before making out the financial plan. Such information may be contained in the following information sources:

- financial reporting: the state of assets and liabilities 
at a certain date, income and expenses, financial results;

- tax reporting: taxes and compulsory payments to the national budget;

- accounting data: detailed information on individual accounts;

- inventory accounting data: detailed information on the movement of material resources;

- previous plans: information for comparison

Systematisation and display of information with the help of tables and graphs involves compilation of Excel spreadsheets, allowing to make analytical calculations and plot various diagrams.

Writing of explanatory statements. At this stage, an explanatory note should be made, in which principles and methods of the indicators' calculation are defined, managerial decisions are grounded. The key to writing these explanations is to provide information in a clear and accessible form. At the same time, it is important to keep to the essence and completeness of the following entries.

Finally, the presentation of a completed plan is carried out. Afterwards, it should be approved and monitored during the entire progress of implementation.

\section{CONCLUSIONS AND PROPOSALS}

The result of the conducted research was as following:

1. It has been established that in order to solve the problem of financing insufficiency at small business enterprises, strategic and tactical financial management can be applied through appropriate planning.

2. It has been noted that financial management should take place at all stages of the movement of funds: formation, distribution and use.

3. It has been determined that strategic financial planning should provide optimization of financial and economic activities and find reserves for increasing profitability. Therefore, the need to introduce the following information into strategic financial plans of small enterprises has been substantiated: production and sales volumes, movement of funds, forecasting of revenues, expenses and financial results, projection of balance, forecast of investment attraction, calculation of the breakeven point and safety margin, indicators that reflect specifics of activities.

4. It has been estimated that tactical plans can work out in detail strategic plans and provide the increased efficiency of activities.

5. The key issues of financial planning have been highlighted.

6. For the management staff of small business enterprises, it has been proposed to work out a procedure for development and approval of financial plans in order to determine the forms, content and responsible persons for preparation, approval, implementation and monitoring of these plans.
7. It has been substantiated that the process of development of financial plans for small business enterprises should take place in four consecutive stages: collection and classification of the information required; systematisation of information with the help of tables and graphs; writing of an explanatory note; submission, approval and further monitoring of implementation of the prepared plan.

Consequently, development of strategic and tactical financial plans for small business enterprises, notwithstanding numerous problems that can arise in the process of such planning, provides better financial management as well as financial and economic security of enterprises in general.

An important issue for successful organisation of financial planning at the real sector enterprises is creation of an effective information and analytical system, which includes: analytical subsystem - principles and methods of financial planning; information subsystem - collection, processing, storage, provision of financial and economic information on the state and dynamics of both internal and external environment of the enterprise.

\section{REFERENCES}

[1] Nepochatenko O.O. Finances of enterprises (Finansy pidpryyemstv). Kyiv, Ukraine: Educational Literature Centre, 2013.

[2] Yu.O. Lytvyn, and V.I. Matviychuk, Financial planning of enterprises in modern conditions (Finansove planuvannya na pidpryyemstvakh $\mathrm{v}$ suchasnykh umovakh), in Current problems of development of financial credit system in Ukraine. Donetsk: Donetsk National University of Technology, 2012. - pp. 67-85.

[3] Scherban O. D. "Types and methods of financial planning at the enterprise", The Young Researcher, no 6 (46). pp. 530-534. 2017.

[4] B.I. Siurkalo, and G.M Shamota. "Methodology of effective financial planning" (Metodolohiya efektyvnoho finansovoho planuvannya), Effective economy, no 1. 2012. [Online]. Available: http://www.economy.nayka.com.ua/?op=1\&z=915. Accessed on: July 12,2019

[5] D. Lazarenko, and S. Sirenko, "Main aspects of the concept of strategic financial planning at the enterprise" (Osnovni aspekty kontseptsiyi stratehichnoho finansovoho planuvannya na pidpryyemstvi), Economic Discussion, p. 2, pp. 64-71, 2016.

[6] H. H. Kireitsev, Financial Management (Finansovyy menedzhment). Kyiv, Ukraine: Educational Literature Centre, 2004.

[7] N. H. Chumachenko, Accounting and analysis in the industrial production (Uchet $\mathrm{i}$ analiz $\mathrm{v}$ promyshlennom proizvodstve). Moscow, Russia: Finance and Statistics, 1971

[8] T. O. Pogorelova, and A. I. Burlaka, "How to achieve a break-even point" (Yak dosyahty tochky bezzbytkovosti), Bulletin of National University of Technology «KhPI», no 32 (1075), pp. 89-93, 2014.

[9] K. K. Yee,."Deep-Value Investing, Fundamental Risks, and the Margin of Safety", Journal of Investing, vol. 17, no. 3, pp. 35-46, 2008 .

[10] L. A. Khromushyna, "Features of financial planning of activities at small business enterprises" (Osoblyvosti finansovoho planuvannya diyal'nosti pidpryyemstv maloho biznesu), Global and national problems of the economy, iss. 23, pp. 574-578, 2018. [Online]. Available: http://global-national.in.ua/archive/23-2018/112.pdf. Accessed on: July 17, 2019

[11] T. O. Kirsanova, and N. A. Diachenko, "Problems and prospects of financial planning at the enterprise" (Problemy ta perspektyvy finansovoho planuvannya na pidpryyemstvi), Bulletin of Sumy State University. "Economics", no. 4, pp. 48-57, 2011. 